\title{
CORRELATION OF TRUST AND WORK ENGAGEMENT: A MODERN ORGANIZATIONAL APPROACH
}

\author{
Ana Nešić1, Slavica Mitrović Veljković ${ }^{2 *}$, Maja Meško ${ }^{3}$ and Tine Bertoncel ${ }^{4}$ \\ ${ }^{1), 2)}$ University of Novi Sad, Novi Sad, Serbia \\ ${ }^{3)}$ University of Primorska, Koper and University of Maribor, Maribor, Slovenia \\ ${ }^{4)}$ University of Primorska, Koper, Slovenia
}

\author{
Please cite this article as: \\ Nešić, A., Mitrović Veljković, S., Meško, M. and \\ Bertoncel, T., 2020. Correlation of Trust and Work \\ Engagement: a Modern Organizational Approach. \\ Amfiteatru Economic, 22(Special Issue No. 14), \\ pp. $1283-1300$
}

DOI: $10.24818 / \mathrm{EA} / 2020 / \mathrm{S} 14 / 1283$

\section{Article History}

Received: 22 April 2020

Revised: 5 August 2020

Accepted: 9 September 2020

\begin{abstract}
In modern organizations, in which changes are happening faster and more unpredictably, employees are gaining a more complex role and increasing importance. New approaches to employee insight, based on the heavy work investment concept (HWI), bring together different theoretical and practical approaches that attempt to explain the causes and consequences of certain organizational behaviors. The fundamental issue is determining whether engagement and trust, remain two of the critical factors of an organizations success, or are their roles in effectively organized systems significantly changed or reduced. This research aims to establish a correlation between trust and work engagement in on 787 respondents from 16 organizations in Serbia. Trust in organizations is measured through the dimensions of benevolence, integrity, competence and predictability. Engagement of employees is measured through the dimensions of energy, dedication and absorption. The results showed a significant correlation between dimensions of trust: benevolence/integrity and competence, with all work engagement dimensions. The strongest correlation is established between the trust dimension of benevolence/integrity and the work engagement dimension - energy. The significance of the research is reflected in the elucidation of behavioral factors of employees in organizations burdened with transitional changes.
\end{abstract}

Keywords: work engagement, trust, organization, HWI concept, employees, Serbia.

JEL Classification: D23, E24, J22, J53, M12.

\footnotetext{
* Corresponding author, Slavica Mitrović Veljković - e-mail: mslavica@ uns.ac.rs
} 


\section{Introduction}

Demands for employees in organizations, a new psychological contract that expects greater autonomy from employees, more responsibility and more commitment, determine new models of organizational behavior.

Although it is challenging to determine all the predictors of employee work behavior, investing time and effort in the work that forms the basis of the HWI concept (Snir and Harpaz, 2011) is the starting point of this research. Prerequisites for investing time and effort of employees in the business must be considered from the organizational and personal aspect. A more precise job specification directs the employees towards cooperation that places the trust among the employees at the forefront, and at the same time, has a positive effect on performance in the business planning scheme. Trust and work engagement are important aspects of employees' working behavior, especially in the context of permanent economic and social changes in society, which also reflects on the status and position of organizations.

Work engagement involves complex attitudes towards work, organization and tasks of employees. Organizational and personal factors that affect work engagement are numerous and depend on the profile of the organization and inter-organizational relationships. Our theoretical framework in the research was Job Demands-Resources. The Job DemandsResources (JD-R) model singles out the work environment as the most important factor for employees (Schaufeli and Bakker, 2004). Work environments consist of two categories: job requirements and job resources. Job requirements can be physical, social or organizational aspects of the job. Job resources are physical, social, or achievement-oriented organizational factors goals at work and form the essence of work behavior. Job resources are all physical, organizational and social aspects of the job that are related to the goals of the job, employee development and alignment of demands with the capabilities of employees. Job requirements are predictors of employee behavior (Bakker and Bal, 2010), while the work resources were the most important predictors of work engagement (Hakanen, Perhoniemi and Toppinen-Tanner, 2008). According to this model, job requirements and job resources are necessary to perform the job.

Employers' demands on employees in contemporary business conditions are increasingly raising many heavy work investment issues, not just the positive heavy work investment subtypes, such as engagement (Harpaz and Snir, 2015).

The HWI concept must be viewed from different aspects, and as research shows, HWI can lead to positive or negative performance (Houlfort et al., 2013). The hard labour investment model (HWI) is also associated with a burnout at work.

\section{Literature review}

One of the potential predictors of HWI is work engagement (Taris, Van Beek and Schaufeli 2015). Employee engagement is a segment of organizational behavior in which employees are motivated, self-developing and productive (Harley, Lee and Robinson, 2005; Shkoler and Tziner, 2020), as well as in line with the culture of the organization and its business strategy. 
Garber (2007) identifies ten key employee engagement factors: commitment, attitude towards organization and work, a uniform recognition system and awards that support organizational strategies, communication (should be effective, consistent, honest and twoway), goal compliance, focus on consumers or customers, a commitment of employees at all levels of the organization, loyalty (that is honest and not instrumental), employee involvement and ownership (in terms of responsible behavior that is not different from the behavior of the owner of the organization) (Garber, 2007).

The engagement of employees is defined as an affective-cognitive state which requires both thinking and feelings in order to develop adequate work engagement (Schaufeli et al., 2002). The ability of cognitive engagement is the potential of work engagement in terms of cognitive capacity, and it can be described as cognitive empowerment for engagement. According to Rothbard, the engagement of employees is measured through two dimensions: the degree of absorption of employees and the degree of their attention, where attention is defined as the time spent in thinking and focusing on the work role, while absorption refers to the intensity of the focus of an individual (Rothbard, 2001). The multidimensional approach by Saks distinguishes engagement at work (performance of a work role) and organizational engagement. Work engagement exists as a unique construct that consists of cognitive, emotional and behavioral components that are related to work roles (Saks, 2006; Bertoncelj, 2010; Dinu, 2016). The recent work of Saks found that the level of work engagement can be predicted due to the perceived support provided by the organization to its employees and that the levels of engagement envisage levels of job satisfaction, commitment measures, intentions of cessation of work and positive behavior within the organization. Research on the engaged employee and his characteristics has shown that a truly engaged employee is one who loves his work, who feels connected with his organization, and who is involved in the events in the organization (Sant, 2016; Roblek et al., 2020).

Besides, the meta-analysis of data collected by the Gallup Organization (Harter, Schmidt and Haye, 2002) yielded similar results, stating the strong effects of employee satisfaction and engagement on their performance and the level of customer satisfaction and loyalty. A weaker, but practically significant effect is also found between the measures of engagement and satisfaction, and outcomes at the business level. In the second meta-analytical study, led by Rikett, a correlation was found between the measures of organizational engagement, observed through attitudes, defined as the relative strength of an individual's identification and involvement in a particular organization - and doing a job (Riketta, 2002). Engagement can also be defined as a long-term commitment, a written or unwritten agreement between the parties (Welbourne, 2007), or as a presentation of a state of significant emotional and cognitive investment (Harter, Schmidt and Keyes, 2003). It is a situation in which individuals are emotionally and intellectually committed to their work, which is also the level at which employees put their efforts into their work in the form of additional time and energy (Doğan, 2002).

Schaufeli and his colleagues defined it as a real fulfilment of the working state of mind, characterized by power, dedication, and absorption (Schaufeli et al., 2002). Schaufeli and Bakker have proposed a model that considers working engagement as a psychological condition that mediates between the impact of work and personal characteristics on the outcomes of the organization (Schaufeli and Bakker, 2010). Using four independent samples, Schaufeli and Bakker showed that work engagement mediated the relationship

Vol. $22 \cdot$ Special No. $14 \cdot$ November 2020 
between work resources and intentions to engage. Also, various longitudinal studies have shown that a high level of work engagement over time leads to more significant organizational commitment (Hakanen, Perhoniemi and Toppinen-Tanner, 2008; Boyd et al., 2011), more personal initiatives and innovative behavior at the team level (Hakanen, Perhoniemi and Toppinen-Tanner, 2008; Cirkvenčič et al., 2017), less reported sickness (Schaufeli, Bakker and van Rhenen, 2009), a better performance (Bakker and Bal, 2010), job satisfaction, organizational commitment, commitment to work, and psychological empowerment (Macey and Schneider, 2008).

In a study in three countries, engagement is positively linked to the self-assessment of academic success (Schaufeli et al., 2002). Also, employees who carry positive emotions from their work to their home and vice versa, transfer positive experiences from home to work, their work shows a higher level of engagement, compared to those where there is no positive crossover between these two different areas of life (Montgomery et al., 2003).

Furthermore, there are some indications, which show that work engagement is positively related to health - e.g. lower levels of depression and stress (Schaufeli and Bakker, 2003) and psychosomatic diseases. Finally, work engagement seems to be positively related to work performance. For example, a study involving hundreds of Spanish hotels and restaurants has shown that the level of employee engagement positively influenced the service climate in those hotels and restaurants, which, on the other hand, influenced the phenomenon that employees work a little beyond the scope of their function and job description, also leading to an increase in customer satisfaction (Salanova et al., 2003).

\section{Concept of trust}

Some theorists perceive trust as a behavioral intent, others as communicating with specific choices (Mayer, Davis and Schoorman, 1995; Rousseau et al., 1998). Besides, organizational trust should consider a psychological environment that can be created with the participation of all members, and that is based on the positive expectations that the organization creates (Fulmer and Gelfand, 2012). Williamson believes that trust represents a certain amount of risk (Williamson, 1993). Trust is much more than a rational calculation of an individual, because it often rests on adherence, even on a belief in the presence of an emotional component, as well as expectations that others will treat us in the way that we treat others (Warren, 1999). Trust is a system of mutual expectations, but also a phenomenon that implies that each participant in the interaction provides a sense of security.

Trust positively correlates with affective commitment, reflecting the influence of trust on work motivation (Mayer and Gavin, 2005). Trust enhances teamwork, leadership, goal setting, and performance assessment (Mayer, Davis and Schoorman, 1995; McAllister, 1995; Jones and George, 1998), and it contributes to employee satisfaction and organizational commitment (Flaherty and Pappas, 2013). Theorists have distinguished between two types of trust - interpersonal trust and systemic or non-personal trust. Interpersonal trust is the trust that exists between individuals. Its foundation rests on an emotional relationship between individuals, and it includes the expectations of specific behavior. Systemic trust refers to the trust that exists between individuals and institutions or between institutions themselves. Trust among employees has an impact on business performance according to the results of numerous surveys. 


\section{Current research}

The selection of research variables is based on our perception of problems in the work behavior of employees and the understanding of the connection between work engagement and trust among employees in the organization. Can trust be considered a desirable resource in employee relations? The results of numerous studies have shown that in conditions where the degree of uncertainty is diminished, trust is less demonstrated in behavior. The results showed that trust decreases when the uncertainty, created in the way relationships manifest, is reduced (Coye, Gerbasi and Cook, 2010). In the context of economic and political uncertainty, the level of trust is considered an essential segment in business and interpersonal relationships in the organization.

The objectives of the research are focused on the following issues:

- Is there a link between work engagement and trust among employees in organizations in Serbia?

- Are the dimensions of engagement (energy, dedication and absorption) associated with the trust of employees in the organizations and in what way?

- To what extent are the dimensions of trust (benevolence, integrity, competence and predictability) represented by the employees in the organizations?

- Based on the Job Demands-Resources theory, can trust be treated as a resource, and in which frames?

- How does the HWI concept relate to work engagement and trust?

Research of trust and work engagement in Serbia is almost nonexistent. Thus, the importance of this study is very high, especially in conditions of constant economic and social change.

\section{Research methodology}

\section{1. Research hypotheses}

Hypothesis 1: Employees with higher trust have stronger working engagement in the examined organizations.

Hypothesis 2: The dimensions of trust (benevolence, integrity, competence) correlate with dimensions of engagement (energy, dedication and absorption).

\subsection{Sample respondents}

The research sample consists of 787 respondents from 16 organizations, categorized according to the type of activity of the enterprise, whether belonging to production and service companies, and according to the legal form of the company - public and private ownership. Four enterprises were production-private, four belonged to the IT sector of private ownership, four were private-service, and four were state-owned public enterprises. The type of activity of organizations is as follows: $39.6 \%$ is of production, and $60.4 \%$ is of service type. The ownership structure is as follows: $30.3 \%$ are public companies, and $69.7 \%$ are private companies. Of the 787 respondents, 411 were male (52\%) and $376(48 \%)$ female. The age of the respondents ranged from 20 to 65 years of age. The dominant 
category of respondents was young subjects aged 26 to 35 years of age. The level of education is as follows: with primary school, there are only $4(0.5 \%)$ respondents, with secondary education, there are $223(27 \%)$ respondents, there are $107(13 \%)$ respondents with higher education, and $492(59.6 \%)$ respondents with a university education or more. The length of service in the current company ranged from one year to 35 years. Most of the respondents were in the current company only up to five years, $54 \%$ of them.

\subsection{Questionnaires}

\subsubsection{Trust scale by Tzafrir and Dolan (Tzafrir and Dolan, 2004)}

The Trust Scale created by Tzafrir and Dolan (2004), consists of 16 claims in the form of a Likert type, rated with seven degrees of agreement. The scale initially measures harmony, concern and reliability as dimensions of the trust. The scale was used in numerous studies, and psychometric analysis confirmed its constructive validity and high reliability. The researches with this questionnaire were conducted in China, Russia, and Vietnam (Wittmann-Zhang and Schenker-Wicki, 2012).

In the present research, the factor analysis (principal component analysis) showed that the instrument was highly defined by a common factor explaining $44 \%$ of the total variance. In addition to the Guttman-Kaiser criterion (eigenvalues $>1$ ), the instrument can be treated a three-dimensional construct. After the oblique Promax rotation presented in table no. 1, the pattern matrix showed that significant three factors could be named as benevolenceintegrity, competence, and unpredictability.

Table no. 1. Results of factor analysis (explained variance, pattern matrix, a correlation between factors) and reliability for the trust scale

\begin{tabular}{|c|c|c|c|}
\hline \multirow[t]{2}{*}{ Items } & \multicolumn{3}{|c|}{ Factors } \\
\hline & 1 & 2 & 3 \\
\hline $\begin{array}{l}\text { 1. Managers'/ employees' needs and desires are } \\
\text { very important to employees/ managers. }\end{array}$ & .895 & & \\
\hline $\begin{array}{l}\text { 2. I can count on my employees/ managers to } \\
\text { help me if I have difficulties with my job. }\end{array}$ & & .653 & \\
\hline $\begin{array}{l}\text { 3. Employees/ managers would not knowingly } \\
\text { do anything to hurt the organization. }\end{array}$ & & .653 & \\
\hline $\begin{array}{l}\text { 4. My employees/ managers are open and } \\
\text { upfront with me. }\end{array}$ & .598 & & \\
\hline $\begin{array}{l}\text { 5. I think that the people in the organization } \\
\text { succeed by stepping on other people. }\end{array}$ & -.487 & & .440 \\
\hline $\begin{array}{l}\text { 6. Employees/ managers will keep the promises } \\
\text { they make. }\end{array}$ & .615 & & \\
\hline $\begin{array}{l}\text { 7. Employees/ managers lookout for what is } \\
\text { important to the managers/ employees. }\end{array}$ & .714 & & \\
\hline $\begin{array}{l}\text { 8. Employees/ managers have much knowledge } \\
\text { about the work that needs to be done. }\end{array}$ & & .908 & \\
\hline $\begin{array}{l}\text { 9. Employees/ managers are known to be } \\
\text { successful in the things they attempt to } \\
\text { accomplish. }\end{array}$ & & .923 & \\
\hline
\end{tabular}




\begin{tabular}{|c|c|c|c|}
\hline \multirow[t]{2}{*}{ Items } & \multicolumn{3}{|c|}{ Factors } \\
\hline & 1 & 2 & 3 \\
\hline $\begin{array}{l}\text { 10. If I make a mistake, my employees/ } \\
\text { managers are willing to 'forgive and forget'. }\end{array}$ & & .537 & .367 \\
\hline $\begin{array}{l}\text { 11. Employees'/ managers' actions and } \\
\text { behaviors are not consistent. }\end{array}$ & & & .896 \\
\hline $\begin{array}{l}\text { 12. Employees/ managers take actions that are } \\
\text { consistent with their words. }\end{array}$ & & & .741 \\
\hline $\begin{array}{l}\text { 13. It is best not to share information with my } \\
\text { employees/ managers. }\end{array}$ & -.344 & & .381 \\
\hline $\begin{array}{l}\text { 14. There is much warmth in the relationships } \\
\text { between the managers and workers in this } \\
\text { organization. }\end{array}$ & .916 & & \\
\hline $\begin{array}{l}\text { 15. Employees/ managers would make personal } \\
\text { sacrifices for our group. }\end{array}$ & .552 & & \\
\hline $\begin{array}{l}\text { 16. Employees/ managers express their true } \\
\text { feelings about important issues. }\end{array}$ & .761 & & \\
\hline \multicolumn{4}{|l|}{ Correlations between factors } \\
\hline 2. Competence & & .619 & -.454 \\
\hline 3. Unpredictability & & & -.393 \\
\hline Variance extraction & $\lambda$ before rot & $\%_{\text {explained s }}^{2}$ & $\lambda$ after rot \\
\hline 1. Benevolence - Integrity & 6.893 & 43.078 & 6.104 \\
\hline 2. Competence & 1.374 & 8.585 & 5.255 \\
\hline 3. Unpredictability & 1.215 & 7.592 & 3.367 \\
\hline Reliability & $\alpha_{\mathrm{C}}$ & Nitems & key \\
\hline 1. Benevolence - Integrity & .893 & 7 & 1467141516 \\
\hline 2. Competence & .786 & 5 & 238910 \\
\hline 3. Unpredictability & .698 & 4 & 5111213 \\
\hline
\end{tabular}

Source: Tzafrir and Dolan, 2004

The key to the analysis of the results, taken from the scale's authors, proved to be insufficiently precise for the interpretation of factors. Namely, the results obtained through the factor analysis showed that the reached factor structure does not correspond to the one that is predicted and given in the author's research. It seemed like the attained factor structure better fits to the results of the conceptual analysis that showed how factors of this scale should be named benevolence, integrity, competence and unpredictability (Dietz and Den Hartog, 2006). Another possible reason is found in language barriers in terms of words that explain certain phenomena in different linguistic areas.

Correlations between these factors have moderate strength (table no. 1). As can be seen in table 1 , the reliability of these scales measured by the Cronbach alpha coefficient is outstanding: $.89, .79$ and .70. The variables benevolence-integrity, competence, and unpredictability were calculated as summative scores on the subscales formed according to the pattern matrix.

Descriptive analysis of the scores' distributions on the subscales showed that just competence had significantly negatively skewed distribution (table no. 3). It was probably caused by the tendency of participants to evaluate the work and competencies of their colleagues positively. 


\subsubsection{Utrecht Work Engagement scale-UWES (Schaufeli and Bakker, 2003}

The Utrecht Work Engagement Scale (UWES), compounded by Schaufeli and Bakker (2003), consists of 17 claims in the form of seven-degree Likert scale questions. Work engagement is measured through three dimensions named energy, dedication and absorption (see table no. 2).

Table no. 2. Results of factor analysis - explained variance, pattern matrix, a correlation between factors and reliability for the three-dimensional solution of the UWE questionnaire

\begin{tabular}{|c|c|c|c|}
\hline \multirow{2}{*}{ Items } & \multicolumn{3}{|c|}{ Factors } \\
\hline & 1 & 2 & 3 \\
\hline 1. At my work, I feel bursting with energy. & .845 & & \\
\hline 2. I find the work that I do full of meaning and purpose. & & & -.641 \\
\hline 3. Time flies when I'm working. & .348 & & \\
\hline 4. At my job, I feel strong and vigorous. & .757 & & \\
\hline 5. I am enthusiastic about my job. & .389 & & -.565 \\
\hline $\begin{array}{l}\text { 6. When I am working, I forget everything else around } \\
\text { me. }\end{array}$ & & & -.407 \\
\hline 7. My job inspires me. & & & -.782 \\
\hline 8. When I get up in the morning, I feel like going to work. & .616 & & \\
\hline 9. I feel happy when I am working intensely. & & .387 & \\
\hline 10. I am proud of the work that I do. & & & -.592 \\
\hline 11. I am immersed in my work. & & .639 & \\
\hline 12. I can continue working for very long periods at a time. & & .665 & \\
\hline 13. To me, my job is challenging and interesting. & & & -.822 \\
\hline 14. I get carried away when I'm working. & & .599 & \\
\hline \multicolumn{4}{|l|}{ 15. At my job, I am very resilient, mentally. } \\
\hline 16. It is difficult to detach myself from my job. & & .582 & \\
\hline $\begin{array}{l}\text { 17. At my work, I always persevere, even when things } \\
\text { do not go well. }\end{array}$ & & .623 & \\
\hline \multicolumn{4}{|l|}{ Correlations between factors } \\
\hline Absorption & & .486 & -.740 \\
\hline Undedication & & & -.656 \\
\hline Variance extraction & $\begin{array}{c}\lambda \text { before } \\
\text { rot }\end{array}$ & $\begin{array}{c}\% \text { explained } \\
2 \\
\mathrm{~s}^{2}\end{array}$ & $\lambda$ after rot \\
\hline Energy & 8.892 & 52.307 & 6.325 \\
\hline Absorption & 1.345 & 7.912 & 5.994 \\
\hline Undedication & .953 & 5.607 & 7.515 \\
\hline Reliability & $\alpha_{\mathrm{C}}$ & $\mathbf{N}_{\text {items }}$ & Key \\
\hline Energy & .888 & 4 & 1348 \\
\hline Absorption & .834 & 6 & 9111214161 \\
\hline Undedication & .915 & 6 & 25671013 \\
\hline
\end{tabular}

Source: Schaufeli and Bakker, 2003 
This scale (Schaufeli and Bakker, 2003) was confirmed in several countries, including China (Yi-Wen and Yi-Qun 2005), Finland (Hakanen, Perhoniemi and Toppinen-Tanner, 2008), Greece (Xanthopoulou, Bakker and Fischbach, 2013), South Africa (Storm and Rothmann, 2003), Spain and the Netherlands (Schaufeli and Bakker, 2003).

For these studies, confirmatory factor analysis was applied, which provides insight into the validation and verification of questionnaire standardization, confirming that the suitability of the presumed three-factor structure, according to the data, was superior to other alternative factor structures, and the high level of the Cronbach alpha coefficient was related to the reliability of the questionnaire (see table no. 3).

Table no. 3. Descriptive statistics for researched variables

\begin{tabular}{|l|c|c|c|c|c|c|}
\hline & Min & Max & Mean & SD & $\mathbf{z}(\mathbf{s k})$ & $\mathbf{z}(\mathbf{k})$ \\
\hline $\begin{array}{l}\text { Benevolence - } \\
\text { Integrity }\end{array}$ & 1.17 & 7 & 4.472 & 1.217 & -1.678 & -0.621 \\
\hline Competence & 2.4 & 7 & 5.335 & 0.963 & -4.322 & -1.724 \\
\hline Unpredictability & 1 & 7 & 3.233 & 1.175 & 2.138 & 0.523 \\
\hline Energy & 1 & 7 & 4.67 & 1.346 & -3.897 & -1.029 \\
\hline Absorption & 1.5 & 7 & 5.246 & 0.992 & -5.115 & 1.316 \\
\hline Undedication & 1 & 7 & 4.942 & 1.289 & -7.437 & 1.121 \\
\hline Work Engagement & 1.53 & 7 & 4.908 & 1.012 & -4.414 & -0.494 \\
\hline
\end{tabular}

Note: $\mathrm{z}(\mathrm{k})$ - deviation from Mean; $\mathrm{z}(\mathrm{sk})$ - deviation from Mean for a sample.

Source: Calculations made by authors

In this study, the factor analysis (maximum likelihood) showed that the instrument was highly determined by a common factor explaining $54 \%$ of the total variance. In addition, it can be treated as a three-dimensional Guttman-Kaiser criterion (eigenvalues >1). Factor analysis of the work engagement scale regarding variance extracted by the first component, as well as the significance of loadings in the component matrix, showed that the instrument could be recognized as a one-dimensional measure of work engagement (see table no. 4).

Table no. 4. Pearson's correlations between trust and work engagement dimensions $(\mathrm{N}=787)$

\begin{tabular}{|l|c|c|c|c|c|}
\hline \multicolumn{2}{|c}{} & Work engagement & Energy & Absorption & Dedication \\
\hline \multirow{2}{*}{ Benevolence-Integrity } & $\mathrm{r}$ & $.606^{* *}$ & $.629^{* *}$ & $.456^{* *}$ & $.581^{* *}$ \\
\cline { 2 - 6 } & $\mathrm{p}$ & .000 & .000 & .000 & .000 \\
\hline \multirow{2}{*}{ Competence } & $\mathrm{r}$ & $.580^{* *}$ & $.538^{* *}$ & $.505^{* *}$ & $.554^{* *}$ \\
\cline { 2 - 6 } & $\mathrm{p}$ & .000 & .000 & .000 & .000 \\
\hline \multirow{2}{*}{ Unpredictability } & $\mathrm{r}$ & $-.396^{* *}$ & $-.412^{* *}$ & $-.332^{* *}$ & $-.377^{* *}$ \\
\cline { 2 - 6 } & $\mathrm{p}$ & .000 & .000 & .000 & .000 \\
\hline
\end{tabular}

Source: Calculations made by authors

Insignificant component loading had the item Work-related stories and ongoings do not have too much influence on me. The reliability of the scale one-dimensionally observed, is high (Cronbach alpha is .948). However, the three-dimensional solution also had a 
rationale. After Promax oblique rotation of the factors and with it, we confirmed previous research that found the factors energy, absorption and dedication. Correlations between these factors are strong, which is another proof of one-dimensionality, but on the other hand, the pattern matrix is interpretable as it can be observed in table no. 5. The variables energy, absorption, and dedication were calculated as summative scores on the subscales formed according to pattern matrix.

Descriptive analysis of the distribution of the scores on the work engagement subscales showed that all of them had significantly negatively skewed distribution (table no. 3 ). The strongest inclination from normal distribution was found for dimension dedication and the lowest for energy. It was probably caused by the tendency of participants to evaluate the work and competencies of their colleagues positively. It revealed the tendency of participants to show themselves as diligent and dedicated workers.

\section{Research results}

Statistical analysis was performed in the SPSS statistical program. Based on the research results obtained, there is a correlation between trust and work engagement with the following indicators:

- It was found that all variables from both sets are significantly related (see table no. 4);

- It was found that variables from both sets form significantly correlated canonical functions (see table no. 5);

- The strongest correlation was between benevolence-integrity and energy $(r=.63, p<.01)$.

Table no. 5. Canonical correlations and significant testing

\begin{tabular}{|c|c|c|c|c|c|c|}
\hline Rc & Eigenvalue & Wilks statistic & F & Df1 & Df2 & p \\
\hline .682 & .869 & .492 & 71.349 & 9.000 & 1900.899 & .000 \\
\hline .274 & .081 & .921 & 16.513 & 4.000 & 1564.000 & .000 \\
\hline .067 & .005 & .995 & 3.568 & 1.000 & 783.000 & .059 \\
\hline
\end{tabular}

Source: Calculations made by authors

A canonical correlation, which measures the strength of the connection between two sets of variables, analysis was conducted using the three dimensions of trust (benevolenceintegrity, competence, and unpredictability) as predictors of the three engagement dimensions (energy, absorption, and dedication) to evaluate the multivariate shared relationship between the two variable sets. The analysis yielded three functions with squared canonical correlations of $.465, .075$, and .004 for each successive function.

Collectively, the full model across all functions was statistically significant using the Wilks's $\lambda=.492$ criterion, $F(9,1900.899)=71.349, \mathrm{p}<.001$. For the set of three canonical functions, the $\mathrm{r}^{2}$ type effect size was .508 , which indicates that the full model explained a substantial portion, about $51 \%$, of the variance shared between the variable sets.

As noted in table no. 5, the full model (Functions 1 to 3 ) was statistically significant. Functions 2 to 3 were statistically significant, $F(4,1564)=16.513, p<.001$, while function 3 did not explain a statistically significant amount of shared variance between the variable 
sets, $\mathrm{F}(1,783)=3.568 \mathrm{p}=.059$. Given the $\mathrm{R}_{\mathrm{c}}{ }^{2}$ significance and effects for each function, just the first two functions were considered important in the context of this study $(46.5 \%$ and $7.5 \%$ of the shared variance, respectively). The last functions only explained $0.5 \%$, of the remaining variance in the variable sets after the extraction of the prior functions. Table no. 6 presents the standardized canonical function coefficients and structure coefficients for Functions 1 and 2.

The squared structure coefficients are also given as well as the communalities $\left(\mathrm{h}^{2}\right)$ across the two functions for each variable.

Looking at the Function 1 structure coefficients (table no. 6), one sees that relevant criterion variables were primarily energy, dedication and absorption. Regarding the predictor variable set in Function 1, benevolence-integrity, competence, and unpredictability contributed to the predictor synthetic variable, respectively. Because the structure coefficient for unpredictability was positive, it was negatively related to all of the engagement dimensions. These results support the theoretically expected relationships, which is that stronger trust is based on benevolence, integrity, competence, and predictability leads to higher engagement at work based on energy, dedication, and absorption.

We could label this function as "engagement based on trust". Function 2 and the coefficients in table no. 6 suggest that the only criterion variable of relevance was absorption. As for trust, competence was the only significant predictor. Given the nature of these variables, we could label this function as "professionalism".

Table no. 6. Canonical solution for trust predicting engagement for both functions

\begin{tabular}{|l|c|c|c|c|r|}
\hline \multirow{2}{*}{ Set 1 } & \multicolumn{2}{|c|}{ Function 1 } & \multicolumn{2}{c|}{ Function 2 } & \multirow{2}{*}{$\mathbf{h}^{\mathbf{2}}(\boldsymbol{\%})$} \\
\cline { 1 - 5 } & $\mathrm{r}_{\mathrm{s}}$ & $\mathrm{r}_{\mathrm{s}}{ }^{2}(\%)$ & $\mathrm{r}_{\mathrm{s}}$ & $\mathrm{r}_{\mathrm{s}}{ }^{2}(\%)$ & \\
\hline Benevolence-Integrity & $\mathbf{- . 9 6 1}$ & 92.35 & .264 & 6.97 & $\mathbf{9 9 . 3 2}$ \\
\hline Competence & $\mathbf{- . 8 3 1}$ & 69.06 & $\mathbf{- . 5 5 5}$ & 30.80 & $\mathbf{9 9 . 8 6}$ \\
\hline Unpredictability & $\mathbf{. 6 2 6}$ & 39.19 & -.191 & 3.65 & 42.84 \\
\hline Variance Explained & .669 & & .138 & & \\
\hline Redundancy & .311 & & .193 & & \\
\hline \multicolumn{1}{|c|}{ Set 2 } & & & & & \\
\hline Energy & $\mathbf{- . 9 5 4}$ & 91.01 & .297 & 8.82 & $\mathbf{9 9 . 8 3}$ \\
\hline Absorption & $\mathbf{- . 7 7 4}$ & 59.91 & -.428 & 18.32 & $\mathbf{7 8 . 2 3}$ \\
\hline Dedication & $\mathbf{- . 9 3 3}$ & 87.05 & -.274 & 7.51 & $\mathbf{9 4 . 5 6}$ \\
\hline Variance Explained & .793 & & .116 & & \\
\hline Redundancy & .369 & & .009 & & \\
\hline
\end{tabular}

Note: Structure coefficients $\left(\mathrm{r}_{\mathrm{s}}\right)$ greater than $|.30|$ are bold. Communality coefficients $\left(\mathrm{h}^{2}\right)$ greater than $45 \%$ are bold; $r_{s}=$ structure coefficient; $r_{s}^{2}=$ squared structure coefficient; $h^{2}=$ communality coefficient.

Source: Calculations made by authors 
Multiple regression analyses were used to test if the dimensions of trust (benevolence integrity, competence, and unpredictability) significantly predicted participants' scores on the work engagement as well as on its dimensions (see table no. 7) in order to find the pattern of the relationships between dimensions of the trust and engagement.

Table no. 7. Results of multiple regression analyses

\begin{tabular}{|c|c|c|c|c|c|c|c|}
\hline \multirow{2}{*}{$\begin{array}{l}\text { Dependent } \\
\text { Variable: }\end{array}$} & \multirow[t]{2}{*}{ Predictors } & \multicolumn{3}{|c|}{ Coefficients } & \multirow[t]{2}{*}{$\mathbf{t}$} & \multirow[t]{2}{*}{ Sig. } & \multirow[t]{2}{*}{ VIF } \\
\hline & & $\mathrm{b}$ & $\mathrm{SE}(\mathrm{b})$ & Beta & & & \\
\hline \multirow{4}{*}{$\begin{array}{l}\text { Work } \\
\text { Engagement }\end{array}$} & (Constant) & 1.727 & .235 & & 7.334 & .000 & \\
\hline & Benevolence-Integrity & .320 & .032 & .385 & 10.015 & .000 & 2.037 \\
\hline & Competence & .343 & .037 & .326 & 9.389 & .000 & 1.669 \\
\hline & Unpredictability & -.024 & .029 & -.028 & -.853 & .394 & 1.536 \\
\hline \multirow[t]{4}{*}{ Energy } & (Constant) & .825 & .314 & & 2.630 & .009 & \\
\hline & Benevolence-Integrity & .509 & .043 & .460 & 11.965 & .000 & 2.037 \\
\hline & Competence & .323 & .049 & .231 & 6.640 & .000 & 1.669 \\
\hline & Unpredictability & -.048 & .038 & -.042 & -1.250 & .212 & 1.536 \\
\hline \multirow[t]{4}{*}{ Absorption } & (Constant) & 2.739 & .258 & & 10.595 & .000 & \\
\hline & Benevolence-Integrity & .163 & .035 & .200 & 4.661 & .000 & 2.037 \\
\hline & Competence & .363 & .040 & .353 & 9.065 & .000 & 1.669 \\
\hline & Unpredictability & -.050 & .032 & -.060 & -1.595 & .111 & 1.536 \\
\hline \multirow[t]{4}{*}{ Dedication } & (Constant) & 1.035 & .309 & & 3.349 & .001 & \\
\hline & Benevolence-Integrity & .396 & .042 & .374 & 9.445 & .000 & 2.037 \\
\hline & Competence & .415 & .048 & .310 & 8.660 & .000 & 1.669 \\
\hline & Unpredictability & -.025 & .038 & -.022 & -.653 & .514 & 1.536 \\
\hline
\end{tabular}

Source: Calculations made by author

The assumptions for doing these analyses (linear relationships, homoscedasticity, no multicollinearity, normal distribution of residuals) were satisfied for all models (table no. 7).

The results of the first regression indicated that scores on the subscales benevolence integrity, competence, and unpredictability explained $43 \%$ of the summative score on the Work engagement (Adjusted $\mathrm{R}^{2}=.43, \mathrm{~F}(3,783)=199.56, \mathrm{p}<.01$ ). It was found that both benevolence - integrity $(\beta=.39, \mathrm{p}<.01)$ and competence $(\beta=.33, \mathrm{p}<.01)$ significantly predicted work engagement.

The results of the second regression indicated that scores on the subscales benevolence integrity, competence, and unpredictability explained $43 \%$ of the summative score on the energy (Adjusted $\left.\mathrm{R}^{2}=.43, \mathrm{~F}(3,783)=197.87, \mathrm{p}<.01\right)$. It was found that both benevolence integrity $(\beta=.46, p<.01)$ and competence $(\beta=.23, p<.01)$ significantly predicted energy.

The results of the third regression indicated that scores on the subscales benevolence integrity, competence, and unpredictability explained $29 \%$ of the summative score on absorption (Adjusted $\mathrm{R} 2=.29, \mathrm{~F}(3.783)=106.21, \mathrm{p}<.01$ ). It was found that both 
benevolence - integrity $(\beta=.20, \mathrm{p}<.01)$ and competence $(\beta=.35, \mathrm{p}<.01)$ significantly predicted absorption.

The results of the fourth regression indicated that scores on the subscales benevolence integrity, competence, and unpredictability explained $40 \%$ of the summative score on the dedication (Adjusted $\mathrm{R} 2=.40, \mathrm{~F}(3.783)=172.39$, $\mathrm{p}<.01$ ). It was found that both benevolence - integrity $(\beta=.37, \mathrm{p}<.01)$ and competence $(\beta=.31, \mathrm{p}<.01)$ significantly predicted dedication.

The comparison of the results showed that energy is better predicted with benevolenceintegrity, while absorption is better predicted with competence. Work engagement and dedication are almost equally predicted with benevolence - integrity and competence.

\section{Discussion of results}

This research and all three types of analysis confirmed that there is a correlation between trust and work engagement. The analyses of the structure of relationships between dimensions gave us better insight in the relationships between dimensions of the trust (benevolence/integrity, competence and predictability) and engagement (energy, absorption and dedication). Both benevolence/integrity and competence had moderately strong correlations with all work engagement dimensions. The strongest correlation is established between the trust dimension of benevolence/integrity and the work engagement dimension - energy reflecting that trust in co-workers results with the stronger energy of employees.

Regression analyses showed that trust in the benevolence and integrity of managers and other employees had the strongest positive impact on energy, stronger trust in the competence of managers and other employees results in higher absorption. In contrast, both dimensions of trust had an almost equal effect on dedication. It seems that trust in coworkers results in developing positive affection towards work, while trust in their competence leads us to concentrate on our work without worrying that there is some uncertainty in the future of the organization. We could also explain this structure of relationships with the affective nature of benevolence/integrity and energy and cognitive nature of competence and absorption.

These results are by findings that trust can contribute to work engagement, by allowing employees to focus on the work to be done (Mayer and Gavin 2005). In the study conducted by Chugtai and Buckley (2011), the impact of trust on work engagement among employees was tested, and a positive relationship between them was found. Also, the existence of trust stimulates work engagement, in conditions of a higher level of prosocial and cooperative behavior, even under uncertain and ambiguous circumstances, individuals feel secure, and believe that their good deeds will be repaid (Van Dyne et al., 2000).

Unpredictability did not have predictive strength in regressions, and its correlations with dimensions of work engagement could be categorized as weak. This finding could be attributed to its smaller importance of work engagement as well as to its negative direction in a psychometric sense. One more reason for lower correlations of the predictability could be found in the younger structure of the sample.

The results showing significant negative skew of the distribution on the competence indicate that respondents strongly trust in the competence of the managers and co-workers, 
but there was no significant inclination of normality on the other two trust dimensions. It could be because respondents are mostly younger and have less experience. The importance of trust is inherent in its potential for increasing organizational commitment, reducing the rate of absenteeism and leading to higher performance (Schaufeli and Salanova, 2008). Organizations with high levels of trust tend to create products and services with low cost because their employees are motivated, they take risks, create innovations, and accept the vision, mission and values of the organization much more quickly.

Our respondents tended to evaluate their work engagement positively. The negative skewness occurred on all dimensions of work engagement, it was the largest for the dedication, and it was followed by absorption. It could be because they are motivated to show themselves as diligent workers and give socially acceptable answers, but it plainly shows their strong working potential. Higher levels of work engagement are associated with a higher level of employee satisfaction, loyalty, higher productivity, lower fluctuation, less absenteeism, presentism (presence with fear of job loss), fewer accidents at work, a better quality of work done, etc. A series of research has shown a positive link between employee engagement and organizational performance, such as employee retention, productivity, profitability, consumer and customer loyalty, and security. Employees who are more engaged in their work show significantly better work performance. This is also shown by the results of numerous surveys in developed countries (Robison, 2012). The explanation for the findings by numerous authors, which show that stronger trust leads to better functioning at work and higher energy levels, emphasizes to us how an organization must care for both cognitive and affective structure of employees in order to create a productive environment (Simmons et al., 2009).

\section{Conclusion}

The results of the research showed a correlation between trust and work engagement in the examined organizations. The significance of both phenomena is enormous because their existence in organizations is carried out by complex mechanisms that are a function of numerous organizational and managerial propositions. The goal of our research was to prove the examined correlation and its significance to science, practice and future research. Perhaps the most accurate explanation was given by Chughtai and his associates (Chughtai and Buckley, 2008). In their analysis, the researchers found that the relationship between trust and work engagement is mutually reinforcing and leads to a positive spiral effect. The research can also be viewed through the prism of the HWI concept. It contributes to the understanding of personal factors for the successful performance of work, such as work engagement and trust.

The practical implications of the research are reflected in the establishment of organizational and managerial measures to create a climate of organization in which trust would contribute to work engagement and joint work engagement to the establishment of trust. Research on trust and work engagement is important because trust is in the functions of the values that dominate organizations. In Serbia, changes in the social and political system have resulted in changes in value frames, and these new working values are established slowly and under different influences.

In this research, we found that suggested scoring keys are not suitable for our sample and proposed new keys that could be more helpful. Results have also shown us that there is a 
need to work on the clarification of the concept of trust in organizations. Research of trust is not easy, and in new business conditions, it also requires new methodological approaches. For example, Robbins' (2016) research suggests that trust can arise from multiple forms of perceived trustworthiness, and he explains that affective mechanisms play an essential role in its development.

The expected contribution of our research is in understanding the factors that contribute to work engagement of employees and concerning the personal factors of the job requirements. The theoretical impact of paperwork can be seen through the contribution to Job Demands-Resources theory and model, by including the factor of trust, as a motivational trigger for activity and engagement. Honest and dedicated engagement of employees among whom there is trust, is the basis of the concept of JDR resources and a direct link to the HWI concepts.

The limitations of the research are reflected in the selection of the sample, which was not representative and also in the selection of questionnaires. In some future research, much more attention must be paid to various aspects of trust that have an impact on work behavior, especially work engagement.

In economies where profit is prioritized rather than human resources, the negative subtype of Heavy work investment concept is more clearly identified and poses serious problems not only to employers but to employees themselves. Increase and specialization of knowledge create the conditions in which trust is posed as a resource, and at the same time, as demand for work without which it will not be possible to do the job in the future.

\section{References}

Bakker, A. and Bal, M., 2010. Weekly work engagement and performance: A study among starting teachers. Journal of Occupational and Organizational Psychology, 83(1), pp.189-206.

Bertoncelj, A., 2010. Managers' competencies framework: a study of conative component. Economic research - Ekonomska istraživanja, 23(4), pp.91-101.

Boyd, C., Bakker, A., Pignata, S., Winefield, A., Gillespie, N. and Stough, C., 2011. A longitudinal test of the job demands-resources model among Australian university academics. Applied Psychology: An International Review, 60(1), pp.112-140.

Chughtai, A. and Buckley, F. 2008. Work engagement and its relationship with state and trait trust: A conceptual analysis. Journal of Behavioral and Applied Management, 10(1), pp.47-71.

Chughtai, A. and Buckley, F. 2011. Work engagement: antecedents, the mediating role of learning goal orientation and job performance, Career Development International, 16(7), pp.684-705.

Cirkvenčič, F., Bertoncel, T., Bertoncelj, A. and Meško, M., 2017. Analysis of relative prosperity in Romania and Slovenia using the being-loving-having model. Amfiteatru economic, 19(46), pp.822-835.

Coye, C., Gerbasi, A. and Cook, K., 2010. Trust and Transitions in Modes of Exchange. Social Psychology Quarterly, 73(2), pp.176-195. 
Dietz, G. and Den Hartog, D., 2006. Measuring trust inside organizations. Personnel review, 35(5), pp.557-588.

Dinu, V., 2016. The constraints to the economic development in the former socialist EU countries from the Central and Eastern Europe. Amfiteatru Economic, 18(43), pp.499-500.

Doğan, E., 2002. The Impact Of Transformational Leadership Style, Trust in Leader, Being Empowered and Affect. PhD Thesis. Marmara University - Institute of Social Sciences, İstanbul. [online] Available at: <https://tez.yok.gov.tr/UlusalTezMerkezi> [Accessed 12 April 2020].

Flaherty, K. and Pappas, J., 2013. The role of trust in salesperson-sales manager relationships. Journal of Personal Selling \& Sales Management, 20(4), pp.271-278.

Fulmer, A. and Gelfand, M., 2012. At what level (and in whom) we trust: Trust across multiple organizational levels. Journal of Management, 38(4), pp.1167-1230.

Garber, P., 2007. 50-Activities for Employee Engagement. Massachucetts: HRD Press.

Hakanen, J., Perhoniemi, R. and Toppinen-Tanner, S., 2008. Positive gain spirals at work: From job resources to work engagement, personal initiative and work-unit innovativeness. Journal of Vocational Behavior, 73(1), pp.78-91.

Harley, A., Lee, D. and Robinson, D., 2005. How O2 built the business case for engagement. Strategic HR Review, 4(6), pp.24-7.

Harpaz, I. and Snir, R., 2015. Applied psychology series. Heavy work investment: Its nature, sources, outcomes, and future directions. New York, NY: Routledge/Taylor \& Francis Group.

Harter, J., Schmidt, F. and Haye, T., 2002. Business-Unit-Level Relationship between Employee Satisfaction, Employee Engagement, and Business Outcomes: A MetaAnalysis. Journal of Applied Psychology, 87(2), pp.268-279.

Harter, J., Schmidt, F. and Keyes, C., 2003. Well-being in the workplace and its relationship to business outcomes: A review of the Gallup studies Flourishing. In: C.L.M. Keyes and J. Haidt, eds. Positive psychology and the life well-lived. Washington DC: American Psychological Association, pp.205-224.

Houlfort, N., Philippe, F., Robert, P., Vallerand, J. and Ménard, J., 2013. On passion and heavy work investment: personal and organizational outcomes. Journal of Managerial Psychology, 29(1), pp.25-45.

Jones, G. and George, J., 1998. The experience and evolution of trust: implications for cooperation and teamwork. The Academy of Management Review, 23(3), pp.531-536.

Macey, W. and Schneider, B., 2008. The Meaning of Employee Engagement. Industrial and Organizational Psychology, 1, pp.3-30.

Mayer, R., Davis, J. and Schoorman, D., 1995. An integrative model of organizational trust. Academy of Management Review, 20(3), pp.709-734.

Mayer, R. and Gavin, M., 2005. Trust in management and performance: Who minds the shop while the employees watch the boss. Academy of Management Journal, 48(5), pp.874-888.

McAllister, D., 1995. Affect and cognition-based trust as foundations for interpersonal cooperation in organizations. Academy of Management Journal, 38(1), pp.24-59. 
Montgomery, A., Peeters, MCW., Schaufeli, W. and Den Ouden, M., 2003. Work-home interference among newspaper managers: Its relationship with Burnout and engagement. Anxiety, Stress and Coping, 16(2), pp.195- 211.

Riketta, M., 2002. Attitudinal organizational commitment and job performance: a metaanalysis. Journal of Organizational Behavior: The International Journal of Industrial, Occupational and Organizational Psychology and Behavior, 23(3), pp.257-266.

Robbins, B., 2016. Probing the Links Between Trustworthiness, Trust and Emotion: Evidence from Four Survey Experiments, Social Psychology Quarterly, 79(3), pp.284-308.

Robison, J., 2012. Boosting engagement at Stryker. Gallup Management Journal. [online] Available at: <https://tez.yok.gov.tr/UlusalTezMerkezi> [Accessed 12 April 2020].

Roblek, V., Pejić Bach, M., Meško, M. and Bertoncel, T., 2020. Best practices of the social innovations in the framework of the e-government evolution. Amfiteatru economic, 22(53), pp.275-302.

Rothbard, N., 2001. Enriching or depleting? The dynamics of engagement in work and family roles. Administrative Science Quarterly, 46(4), pp.655-684.

Rousseau, D., Sitkin, S., Burt, R. and Camerer, C., 1998. Not so different after all: A crossdiscipline view of trust. Academy of Management Review, 23(3), pp.393-405.

Saks, A., 2006. Antecedents and consequences of employee engagement. Journal of Managerial Psychology, 21(7), pp.600-619.

Salanova, M., Llorens, S., Cifre, E., Martinez, I. and Schaufeli, W., 2003. Perceived collective efficacy, subjective well-being and task performance among electronic work groups: An experimental study. Small Groups Research, 34(1), pp.43-73.

Sant, S., 2016. An Analysis of Credibility of CEO's in an Organisation Linkage with Employee Engagement. Asian Social Science, 12(10), pp.127-135.

Schaufeli, W. and Bakker, A., 2003. Utrecht work engagement scale: Preliminary manual. Utrecht: Occupational Health Psychology Unit, Utrecht University.

Schaufeli, W. and Bakker, A., 2004. Job demands, job resources and their relationship with burnout and engagement: a multi-sample study. Journal of Organizational Behavior, 25(3), pp.293-315.

Schaufeli, W. and Bakker, A., 2010. Defining and measuring work engagement: bringing clarity to the concept. In: A.B. Bakker and M. P. Leiter, eds. Work Engagement: A Handbook of Essential Theory and Research. New York: Psychology Press. pp.10-24.

Schaufeli, W., Bakker, A. and van Rhenen, W., 2009. How changes in job demands and resources predict burnout, work engagement and sickness absenteeism. Journal of Organizational Behavior, 30(7), pp.893-917.

Schaufeli, W. and Salanova, M., 2008. Enhancing work engagement through the management of human resources. In: K. Näswall, M. Sverke and J. Hellgren. eds. The individual in the changing working life. Cambridge: Cambridge University Press. pp.380-404.

Schaufeli, W., Salanova, M., González-Romá, V. and Bakker, A., 2002. The measurement of engagement and burnout: A two sample confirmatory factor analytic approach. Journal of happiness studies, 3(1), pp.71-92.

Shkoler, O. and Tziner, A., 2020. Leadership Styles as Predictors of Work Attitudes: A Moderated-Mediation Link. Amfiteatru economic, 22(53), pp.164-178. 
Snir, R., and Harpaz, I., 2011. Beyond workaholism: Towards a general model of heavy work investment, Human Resource Management Review, 22(3), pp.232-243.

Storm, K. and Rothmann, S. 2003. The relationship between burnout, personality traits and coping strategies in a corporate pharmaceutical group. Journal of Industrial Psychology, 29(4), pp.35-42.

Taris, T.W., Van Beek, I. and Schaufeli, W.B., 2015. The Beauty versus the Beast: On the motives of engaged and workaholic employees. In I. Harpaz and R. Snir (eds.). Heavy Work Investment: Its Nature, Sources, Outcomes, and Future Directions, New York: Taylor and Francis/Routledge. pp.121-138.

Tzafrir, S. and Dolan, S. 2004. Trust Me: A Scale for Measuring Manager Employee Trust. Management Research: Journal of the Iberoamerican Academy of Management, 2(2), pp.115-132.

Tziner, A., Buzea, C., Rabenu, E., Shkoler, O., Truța, C. 2019. Understanding the relationship between antecedents of Heavy Work Investment (HWI) and burnout, Amfiteatru Economic Journal, 21(50), pp.153-176.

Van Dyne, L., Vandewalle, D., Kostova, T., Latham, M. and Cummings, L. 2000. Collectivism, Propensity to Trust and Self-Esteem as Predictors or Organizational Citizenship in a Non-Work Setting. Journal of Organizational Behavior, 21(1), pp.3-23.

Warren, M., 1999. Democratic theory and trust. in Democracy and trust. Cambridge: Cambridge University Press.

Welbourne, T., 2007. Employee engagement: Beyond the fad and into the executive suite. Leader to Leader, 44, pp.45-51.

Williamson, O., 1993. Calculativeness, trust and economic organization. Journal of Law and Economics, 36(1), pp.453-486.

Wittmann-Zhang, X. and Schenker-Wicki, A., 2012. Trust and control across three emerging economies. Cardiff, UK: British Academy of Management. DOI: $10.5167 /$ uzh-72866

Xanthopoulou, D., Bakker, A. and Fischbach, A., 2013. Work Engagement Among Employees Facing Emotional Demands the Role of Personal Resources. Journal of Personnel Psychology, 12(2), p.74-84.

Yi-wen, Z. and Yi-qun, C. 2005. The Chinese version of Utrecht Work Engagement Scale: An examination of reliability and validity. Chinese Journal of Clinical Psychology, 13(3), pp.268-270. 